\title{
Sorghum Grain Quality as Influenced by Plant Density, Nitrogen Nutrition and Cultivar
}

\author{
J.A. Ajidahun, E.T. Sebetha
}

10.18805/IJARe.A-656

\begin{abstract}
Background: Grain sorghum [Sorghum bicolor (L.) Moench] is a staple cereal crop in the semiarid regions of the world, notably in sub-Saharan Africa due to its ability to withstand drought. However, poor soil fertility is one factor that limits its production in small farmers' fields.

Methods: Field experiments were conducted at two locations in the North-West province of South Africa during the 2016/17 and $2017 / 18$ planting seasons. The objective of this study was to determine the effects of plant density, nitrogen $(\mathrm{N})$ fertilizer rates and cultivar on sorghum grain quality. Ash, fiber, oil, protein and starch content were analysed.

Result: $N$ fertilizer rate had a significant effect $(P \leq 0.05)$ on sorghum ash content during the $2017 / 18$ season. Sorghum without $N$ application had significantly higher ash content (4.438\%) than those fertilized with 100 and $150 \mathrm{~kg} \mathrm{~N} / \mathrm{ha}$. Cultivar had a significant effect $(P<0.001)$ on protein content during the $2017 / 18$ season. Sorghum cultivar PAN 8816 had a significantly higher protein content $(8.87 \%)$ than PAN 8625. Location had a significant effect $(P<0.001)$ on starch content during the 2016/17 season. Sorghum planted at Mafikeng had a significantly higher starch content $(38.50 \%)$ than sorghum planted at Taung.
\end{abstract}

Key words: Cultivar, Grain quality, Nitrogen, Plant density, Sorghum.

\section{INTRODUCTION}

Sorghum is a major source of carbohydrates and protein in the diet of rural communities in sub-Saharan Africa (Hikeezi, 2014). Sorghum is high in starch, while some cultivars contain high dietary fiber (Jimoh and Abdullahi, 2017). Typical analytical figures for sorghum grains are; ash $2 \%$, fat $3 \%$, fiber $2 \%$, food energy 394 calories, moisture 11 $12 \%$, protein $10-15 \%$ and starch $68-80 \%$ (Jimoh and Abdullahi, 2017).

$\mathrm{N}$ fertilization is one factor limiting grain quality, as variable responses to the application of $\mathrm{N}$ fertilizer have been observed in sorghum and maize (Kaufman et al., 2013). The effect of $\mathrm{N}$ fertilizers on the grain quality of many cereals has also been investigated extensively (Sedlár et al., 2011; Valkama et al., 2013). Some experiments on wheat have indicated that increasing $\mathrm{N}$ levels lead to an increase in the wheat protein content and similar effects have been found in sorghum and maize (Kaufman et al., 2013; Silva et al., 2019).

Plant density has no effect on the ash content of sorghum (Mahmood et al., 2013). On the other hand, sorghum planted under high plant densities show an increase in protein content. Generally, grain quality varies among different cultivars of sorghum and influenced by the prevailing environmental conditions under which the plants are cultivated (Oyier et al., 2017). Reports by Tang et al. (2018) indicated that high protein content was observed in early maturing cultivars of wheat.

Since nitrogen is a critical nutrient for cereals, its deficiency may limit grain yield and quality (Diallo, 2012). On the other hand, over-fertilization tends to decrease the quality of grains. Therefore, the objective of this study was
Food Security and Safety Niche Area, Faculty of Natural and Agricultural Sciences, North-West University, Mafikeng Campus, Private Bag X 2046, Mmabatho, 2735, South Africa.

Corresponding Author: E.T. Sebetha, Food Security and Safety Niche Area, Faculty of Natural and Agricultural Sciences, NorthWest University, Mafikeng Campus, Private Bag X 2046, Mmabatho, 2735, South Africa. Email: Erick.Sebetha@nwu.ac.za

How to cite this article: Ajidahun, J.A. and Sebetha, E.T. (2021). Sorghum Grain Quality as Influenced by Plant Density, Nitrogen Nutrition and Cultivar. Indian Journal of Agricultural Research. DOI: 10.18805/IJARe.A-656.

Submitted: 24-05-2021 Accepted: 24-07-2021 Online: 06-09-2021

to determine the influence of cultivar, $\mathrm{N}$ fertilizer rates and plant density on sorghum grain quality.

\section{MATERIALS AND METHODS}

\section{Site description}

This study was conducted during the 2016/17 and 2017/18 planting seasons at the Department of Agriculture Experimental Station, Taung, and the North-West University Research Farm, Mafikeng, South Africa. The soils at the sites had different chemical and physical properties (Table 1), and the environmental conditions also differed (Table 2). The North-West University Research Farm is situated at $25^{\circ} 48^{\prime} \mathrm{S}$ and $45^{\circ} 38^{\prime} \mathrm{E}$. This region receives a mean annual rainfall of $571 \mathrm{~mm}$ in summer (Kasirivu et al., 2011).

The Department of Agriculture's experimental station at Taung is situated at $27^{\circ} 30^{\prime} \mathrm{S}$ and $24^{\circ} 30^{\prime} \mathrm{E}$. The experimental site is situated in a grassland savannah region 
with a mean rainfall of $1061 \mathrm{~mm}$, and the rainy season usually starts in October (Pule-Meulenberg et al., 2010).

\section{Experimental design}

The experimental design was a split-split plot arrangement fitted into a randomized complete block design (RCBD) with four replicates. The experiment considered high plant density (33333 plants/ha) with $1 \times 0.3 \mathrm{~m}$ spacing and low plant density (22222 plants/ha) with $1.5 \times 0.3 \mathrm{~m}$ spacing; as the main plot factor. $\mathrm{N}$ fertilizer rates of 0,100 and $150 \mathrm{~kg} \mathrm{~N} / \mathrm{ha}$, were the sub-plot factor, while two sorghum cultivars; PAN 8625 (late-maturity) and PAN 8816 (medium-late-maturity), were the sub-sub plot factor. The field area measured $60 \mathrm{~m} \times$ $36 \mathrm{~m}\left(2160 \mathrm{~m}^{2}\right)$ and the experiment was a total of 48 plots per site.

\section{Agronomic practices}

Seedbeds were prepared through disc ploughing and harrowing. Sorghum cultivars were purchased from PANNAR Seed Company. Each plot measured $6 \mathrm{~m} \times 4 \mathrm{~m}$, with five rows under low plant density and seven rows under high plant density. Urea $(46 \% \mathrm{~N})$ supplied nitrogen, and single superphosphate $(60 \mathrm{~kg} / \mathrm{ha})$ supplied phosphorus. Fertilizers were mixed and applied through banding at planting. Thinning was carried out three weeks after emergence, leaving one plant per stand.

\section{Data collection}

Field dried sorghum panicles were hand-harvested from a harvesting area of $9.6 \mathrm{~m}^{2}$. The panicles from the harvesting area were threshed and winnowed. Approximately $500 \mathrm{~g}$ of

Table 1: The results of soil chemical $\left(\mathrm{mg} \mathrm{kg}^{-1}\right)$ and the physical properties of samples collected before planting at two locations during the 2016/17 and 2017/18 seasons.

\begin{tabular}{|c|c|c|c|c|c|}
\hline \multirow{2}{*}{ Location } & \multirow{2}{*}{$\begin{array}{c}\text { Chemical/physical } \\
\text { properties }\end{array}$} & \multicolumn{2}{|c|}{2016} & \multicolumn{2}{|c|}{2017} \\
\hline & & $0-15(\mathrm{~cm})$ & $15-30(\mathrm{~cm})$ & $0-15(\mathrm{~cm})$ & $15-30(\mathrm{~cm})$ \\
\hline \multirow[t]{8}{*}{ Mafikeng } & $\mathrm{N}-\mathrm{NO}_{3}$ & 4.24 & 8.66 & 8.50 & 10.00 \\
\hline & $\mathrm{N}-\mathrm{NO}_{4}$ & 0.75 & 1.40 & 1.75 & 1.95 \\
\hline & P (Bray-1) & 54 & 54 & 19 & 33 \\
\hline & $\mathrm{K}$ & 268 & 268 & 198 & 195 \\
\hline & $\%$ Sand & 82 & 80 & 81 & 82 \\
\hline & $\%$ Silt & 4 & 6 & 4 & 4 \\
\hline & $\%$ Clay & 14 & 14 & 15 & 14 \\
\hline & $\mathrm{pH}(\mathrm{KCl})$ & 6.26 & 6.07 & 5.28 & 5.24 \\
\hline \multirow[t]{8}{*}{ Taung } & $\mathrm{N}-\mathrm{NO}_{3}$ & 11.06 & 5.39 & 28.50 & 26.75 \\
\hline & $\mathrm{N}-\mathrm{NO}_{4}$ & 0.50 & 0.80 & 1.35 & 1.55 \\
\hline & P (Bray-1) & 9 & 6 & 9 & 8 \\
\hline & $\mathrm{K}$ & 235 & 203 & 188 & 198 \\
\hline & $\%$ Sand & 84 & 82 & 85 & 86 \\
\hline & $\%$ Silt & 3 & 4 & 3 & 3 \\
\hline & $\%$ Clay & 13 & 14 & 12 & 11 \\
\hline & $\mathrm{pH}(\mathrm{KCl})$ & 5.79 & 5.39 & 5.65 & 5.74 \\
\hline
\end{tabular}

Table 2: The mean temperatures and rainfall at Mafikeng and Taung for the duration of the experiment.

\begin{tabular}{|c|c|c|c|c|c|c|c|c|}
\hline Location & Season & Climate data & Dec & Jan & Feb & Mar & Apr & May \\
\hline \multirow[t]{6}{*}{ Mafikeng } & $2016 / 17$ & Rainfall (mm) & 117.2 & 147.8 & 282.8 & 21.0 & 77.6 & 0 \\
\hline & & $\operatorname{Max} \mathrm{T}\left({ }^{\circ} \mathrm{C}\right)$ & 31.5 & 28.5 & 27.2 & 29.4 & 26.5 & 24.5 \\
\hline & & $\operatorname{Min} \mathrm{T}\left({ }^{\circ} \mathrm{C}\right)$ & 18.8 & 17.7 & 17.4 & 13.9 & 11.8 & 6.6 \\
\hline & $2017 / 18$ & Rainfall (mm) & 48.6 & 71.8 & 108.8 & 90.0 & 27.6 & 26.0 \\
\hline & & $\operatorname{Max} \mathrm{T}\left({ }^{\circ} \mathrm{C}\right)$ & 32.4 & 33.8 & 29.7 & 29.6 & 27.0 & 25.2 \\
\hline & & $\operatorname{Min} \mathrm{T}\left({ }^{\circ} \mathrm{C}\right)$ & 16.9 & 18.0 & 17.4 & 15.4 & 12.5 & 7.0 \\
\hline \multirow[t]{6}{*}{ Taung } & $2016 / 17$ & Rainfall (mm) & 145.6 & 241.6 & 155.4 & 13.0 & 42.6 & 0.6 \\
\hline & & $\operatorname{Max} \mathrm{T}\left({ }^{\circ} \mathrm{C}\right)$ & 36.1 & 30.6 & 29.3 & 31.0 & 27.3 & 25.6 \\
\hline & & $\operatorname{Min} \mathrm{T}\left({ }^{\circ} \mathrm{C}\right)$ & 18.2 & 16.9 & 17.8 & 13.2 & 9.2 & 4.7 \\
\hline & $2017 / 18$ & Rainfall (mm) & 31.2 & 41.8 & 49.6 & 126.8 & 107.8 & 1.6 \\
\hline & & $\operatorname{Max} \mathrm{T}\left({ }^{\circ} \mathrm{C}\right)$ & 34.8 & 36.0 & 33.1 & 31.0 & 26.2 & 24.8 \\
\hline & & $\operatorname{Min} \mathrm{T}\left({ }^{\circ} \mathrm{C}\right)$ & 16.8 & 17.8 & 17.9 & 15.4 & 12.7 & 4.4 \\
\hline
\end{tabular}

$\operatorname{Max} \mathrm{T}\left({ }^{\circ} \mathrm{C}\right)=$ Maximum temperature in degree Celsius, Min $\mathrm{T}\left({ }^{\circ} \mathrm{C}\right)=$ Minimum temperature in degree Celsius, $\mathrm{mm}=$ millimeters.

Source: South African Weather Service (SAWS), 2018. 
grain samples were sub-sampled per plot and used for grain analysis. A total of 48 samples per location were analysed for protein, oil, starch, ash and fiber content using the Spectra Star XL near Infrared Analyser (NIR) machine.

\section{Data analysis}

An analysis of variance was performed on the data generated using the GenStat: $11^{\text {th }}$ edition (2008). The least significant difference (LSD) was used to separate the means, and a probability level of less than 0.05 was considered statistically significant (Gomez and Gomez, 1984). The high factor interactions were considered under each measured parameter.

\section{RESULTS AND DISCUSSION}

The effects of cultivar, nitrogen fertilizer rate, plant density and location on the sorghum ash content

Cultivar had a significant effect $(P<0.001)$ on the sorghum ash content during the $2016 / 17$ planting season, as indicated in Fig 1. Sorghum cultivar PAN 8625 had a significantly higher ash content of $4.47 \%$ than PAN 8816 (3.54\%). The difference between the two cultivars in terms of ash content could be attributed to the genetic constitution. This corroborates the findings by Telleng et al. (2016), who reported an increase in the ash content among one of the varieties of sorghum planted.

Nitrogen fertilizer rate and location had a significant effect $(P \leq 0.05)$ on the sorghum ash content during the 2017/ 18 planting season, as indicated in Fig 2 and 3, respectively. Sorghum without nitrogen fertilizer application had a significantly higher ash content of $4.438 \%$ than sorghum fertilized with 100 (4.32\%) and $150 \mathrm{~kg}(4.31 \%) \mathrm{N} / \mathrm{ha}$. These findings are contradictory to the findings by Hassan et al. (2014), who reported increased ash content with increased nitrogen application.

Sorghum planted at Taung had a significantly higher ash content of $4.40 \%$ than sorghum planted at Mafikeng $(4.31 \%)$. These results could be attributed to the difference in soil type, its soil nutrient status and the variable rainfall recorded at the two locations. This corroborates the findings by Jimoh and Abdullahi (2017), who reported that an increase in ash content of sorghum could be attributed to the nature of the soil and the amounts of nutrient in the soil. During the $2017 / 18$ planting season, the interactions of nitrogen fertilizer rate $x$ plant density $x$ location had a significant effect $(P=0.009)$ on the sorghum ash content.

The effects of cultivar, nitrogen fertilizer rate, plant density and location on the sorghum fiber content

Cultivar had a significant effect $(P<0.001)$ on the sorghum fiber content during the $2016 / 17$ and $2017 / 18$ planting seasons, as indicated in Fig 1. Sorghum cultivar PAN 8625 had a significantly higher fiber content of $10.60 \%$ and $9.67 \%$ than PAN 8816, with fiber content of $7.35 \%$ and $7.13 \%$ during the 2016/17 and 2017/18 planting seasons. Ayub et al. (2010) also reported significant differences in fiber content among eight cultivars tested.

Location had a significant effect $(P=0.005)$ on the sorghum fiber content during the 2016/17 planting season, as indicated in Fig 3. Sorghum planted at Taung had a significantly higher fiber content of $9.80 \%$ than sorghum planted at Mafikeng (8.14\%). Variations in the crude fiber contents of various sorghum cultivars were also reported by Telleng et al. (2016) and Hunsigi et al. (2010). Higher fibre content obtained at Taung could also be attributed to better rainfall during growing season as reported by Islam and Sebetha (2020).

During the $2017 / 18$ planting season, the interaction of nitrogen fertilizer rate $\times$ plant density $\times$ location had a significant effect $(P=0.027)$ on the sorghum fiber content.

The effects of cultivar, nitrogen fertilizer rate, plant density and location on the sorghum oil content

Cultivar had a significant effect $(P<0.001)$ on the sorghum oil content during the 2017/18 planting season, as indicated in Fig 1. Sorghum cultivar PAN 8816 had a significantly higher oil content of $5.45 \%$ than PAN 8625 (4.1\%). The

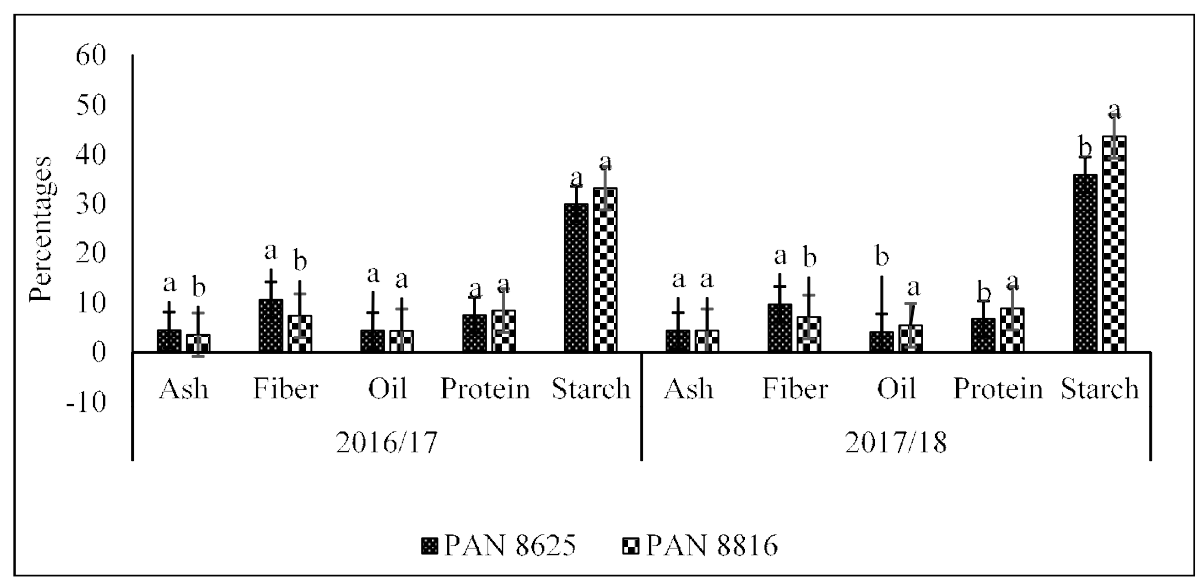

Fig 1: The main effects of cultivar on ash, fiber, oil, protein and starch content of sorghum during the 2016/17 and 2017/18 planting seasons. 
observed differences in oil content could be attributed to the differences in grain size of the two sorghum cultivars. This corroborates the findings by Shen et al. (2010), who reported that the oil content in maize seed is influenced by the size of the seed embryo and the oil concentration in the embryo and endosperm.

Location had a significant effect $(\mathrm{P}<0.001)$ on the sorghum oil content during the 2016/17 and 2017/18 planting seasons, as indicated in Fig 3. Sorghum planted at Mafikeng had a significantly higher oil content of $5.01 \%$ than sorghum planted at Taung (3.69\%) during the 2016/17 planting season. Sorghum planted at Mafikeng also had a significantly higher oil content of $5.01 \%$ than sorghum planted at Taung (4.54\%) during the $2017 / 18$ planting season. This could be attributed to differences in rainfall and temperature prevailed at the two locations. These result corroborate the findings by Mikulíková et al. (2011), who reported that starch content in cereals is significantly influenced by the prevailing weather.

During both seasons, the interactions of cultivar $x$ location had a significant effect on the sorghum oil content.

The effects of cultivar, nitrogen fertilizer rate, plant density and location on the sorghum protein content

Cultivar and location had a significant effect $(P<0.001)$ on the sorghum protein content during the $2017 / 18$ planting season, as indicated in Fig 1 and 3, respectively. Sorghum cultivar PAN 8816 had a significantly higher protein content of $8.87 \%$ than PAN 8625 (6.74\%). In previous studies, Ahmad et al. (2016) also reported significant differences among sorghum cultivars for protein content. Sorghum planted at Taung had a significantly higher protein content of $8.31 \%$ than sorghum planted at Mafikeng (7.31\%). This corroborates the findings by Sebetha et al. (2015), who

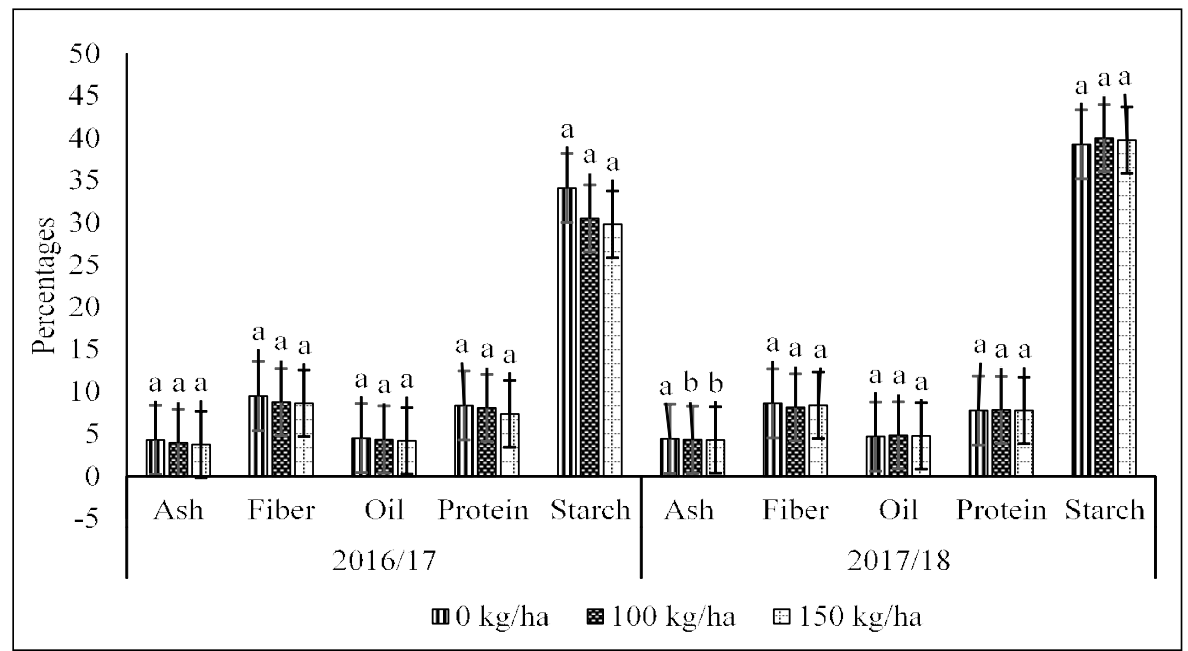

Fig 2: The main effects of nitrogen fertilizer rate on ash, fiber, oil, protein and starch content of sorghum during the 2016/17 and 2017/18 planting seasons.

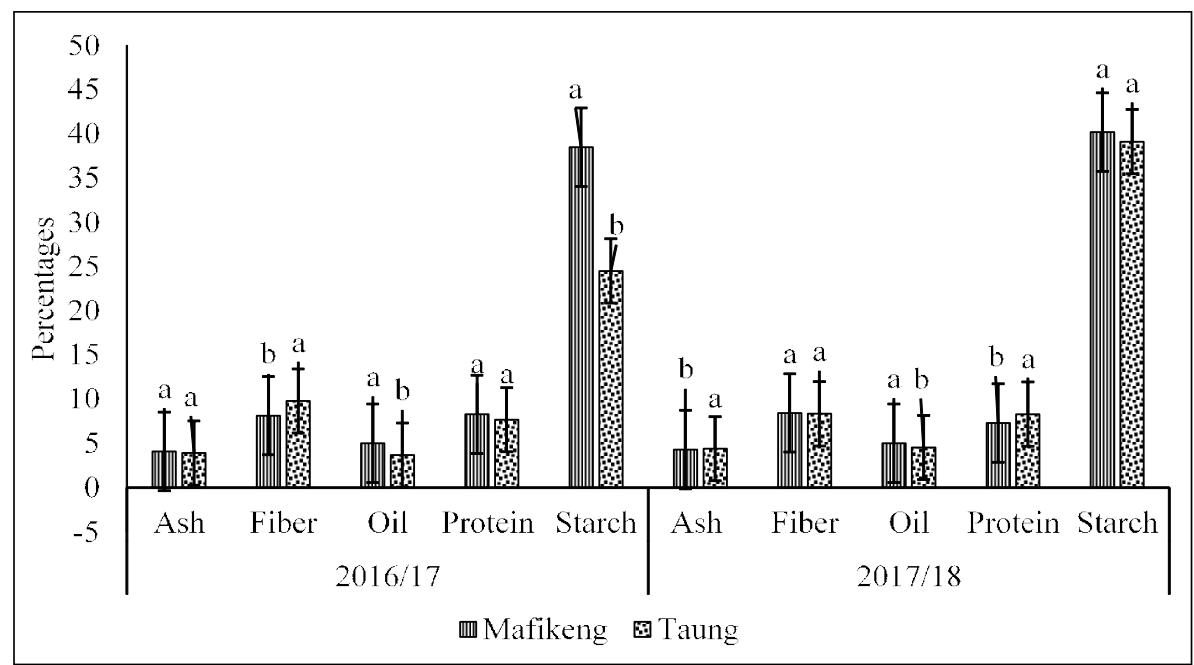

Fig 3: The main effects of location on ash, fiber, oil, protein and starch content of sorghum during the 2016/17 and 2017/18 planting seasons. 
Sorghum Grain Quality as Influenced by Plant Density, Nitrogen Nutrition and Cultivar

reported that maize seeds harvested from Taung had a significantly higher protein content than at Mafikeng.

During the 2016/17 planting season, the interactions of nitrogen fertilizer rate $x$ location had a significant effect $(P<0.045)$ on the sorghum protein content. During the 2017/ 18 planting season, the interactions of cultivar $x$ location had a significant effect $(P=0.032)$ on the sorghum protein content.

The effects of cultivar, nitrogen fertilizer rate, plant density and location on the sorghum starch content

Cultivar had a significant effect $(P<0.001)$ on the sorghum starch content during the $2017 / 18$ planting season, as indicated in Fig 1. Sorghum cultivar PAN 8816 had a significantly higher starch content of $43.55 \%$ than PAN 8625 (35.79\%). These results are consistent with findings by Palavecino et al. (2016), who reported that sorghum cultivars differ significantly in starch content.

Location had a significant effect $(P<0.001)$ on the sorghum starch content during the 2016/17 planting season, as indicated in Fig 3. Sorghum planted at Mafikeng had a significantly higher starch content of $38.50 \%$ than sorghum planted at Taung (24.5\%). The higher starch content from sorghum planted at Mafikeng might be attributed to better environmental conditions such as rainfall and temperature. Adebayo et al. (2021) reported the improved in maize performance from the same location.

During both the planting seasons, the interactions of cultivar $x$ location had a significant effect on the starch content of sorghum.

\section{CONCLUSION}

The results of the grain analysis revealed that the grain quality of sorghum was significantly affected by different treatments. Cultivar, PAN 8625, had higher ash and fiber content than PAN 8816, which showed higher oil, protein, and starch content. Nitrogen rates did not affect the quality of sorghum except ash content. However, interaction was significant among different treatments, which implied that the choice of a cultivar is important in a location, fertility status of soil and plant density to realize improved sorghum yields.

\section{ACKNOWLEDGEMENT}

The authors are grateful to the Department of Crop Science at North-West University, Mafikeng. The study was supported by Food Security and Safety Niche Area (FSS).

\section{REFERENCES}

Adebayo, A.R., Kutu, F.R. and Sebetha, E.T. (2021). Effect of different nitrogen fertilizer rates and plant density on growth of water efficient maize variety under different field conditions. Indian Journal of Agricultural Research. 55(1): 81-86.

Ahmad, S.H.E.R., Ansar, M., Muhammad, I.J.A.Z. and Sattar, A. (2016). Proximate analysis of forage sorghum cultivars with different doses of nitrogen and seed rate. Turkish Journal of Field Crops. 21(2): 276-285.
Ayub, M., Nadeem, M.A., Tahir, M., Ghafoor, A., Ahmed, Z. and Naeem, M. (2010). Comparative studies on the growth, forage yield and quality of sorghum (Sorghum bicolor $L$.) varieties under irrigated conditions of Faisalabad. Pakistan Journal of Life and Social Sciences. 8(2): 94-97.

Diallo, S. (2012). Effect of Genotypes and Nitrogen on Grain Quality of Sorghum. Kansas State University.

Gomez, K.A. and Gomez, A.A. (1984). Statistical Procedures for Agricultural Research. John Wiley and Sons.

Hassan, M.U., Zamir, S.I., Haq, I., Khalid, F., Rasool, T. and Hussain, A. (2014). Growth, yield and quality performance of pearl millet (Pennisetum americanum L.). American Journal of Plant Sciences. 5: 2215-2223.

Hikeezi, D.M. (2014). Sorghum grain: Development of methodologies for end-use quality evaluation (Doctoral dissertation, University of Pretoria).

Hunsigi, G., Yekkeli, N. and Kongawad, B. (2010). Sweet stalk sorghum: An alternative sugar crop for ethanol production. Sugar Technology. 12(1): 79-80.

Islam, M. and Sebetha, E. (2020). Drybean yield under the influence of cultivar, phosphorus fertilizer rate and location. Indian Journal of Agricultural Research. 54(4): 536-540.

Jimoh, W. and Abdullahi, M. (2017). Proximate analysis of selected sorghum cultivars. Bayero Journal of Pure and Applied Sciences. 10(1): 285-288.

Kasirivu, J., Materechera, S. and Dire, M. (2011). Composting ruminant animal manure reduces emergence and species diversity of weed seedlings in a semi-arid environment of South Africa. South African Journal of Plant and Soil. 28(4): 228-235.

Kaufman, R., Wilson, J., Bean, S., Presley, D., Blanco-Canqui, H. and Mikha, M. (2013). Effect of nitrogen fertilization and cover cropping systems on sorghum grain characteristics. Journal of Agricultural and Food Chemistry. 61(24): 5715-5719.

Mahmood, A., Ullah, H., Shahzad, A., Ali, H., Ahmad, S., Zia-Ul-Haq, M., Honermeier, B. and Hasanuzzaman, M. (2013). Dry matter yield and chemical composition of sorghum cultivars with varying planting density and sowing date. Sains Malaysiana. 42(10): 1529-1538.

Mikulíková, D., Horváthová, V., Rückschloss, L., Gavurníková, S., Žofajová, A. and Kraic, J. (2011). Differences between wheat cultivars in grain parameters related to ethanol production. Poljoprivreda. 17(2): 3-7.

Oyier, M.O., Owuoche, J.O., Oyoo, M.E., Cheruiyot, E., Mulianga, B. and Rono, J. (2017). Effect of harvesting stage on sweet sorghum (Sorghum bicolor L.) genotypes in Western Kenya. The Scientific World Journal. 2017.

Palavecino, P.M., Penci, M.C., Calderón Domínguez, G. and Ribotta, P.D. (2016). Chemical composition and physical properties of sorghum flour prepared from different sorghum hybrids grown in Argentina. Starch Stärke. 68(11-12): 1055-1064.

Pule-Meulenberg, F., Belane, A.K., Krasova-Wade, T. and Dakora, F.D. (2010). Symbiotic functioning and bradyrhizobial biodiversity of cowpea (Vigna unguiculatal Walp.) in Africa. BMC Microbiology. 10(1): 89.

Sebetha, E.T., Modi, A.T. and Owoeye, L.G. (2015). Maize seed quality in response to different management practices and sites. Journal of Agricultural Science. 7(1): 215-223. 
Sedlář, O., Balík, J., Kozlovskı, O., Peklová, L. and Kubešová, K. (2011). Impact of nitrogen fertilizer injection on grain yield and yield formation of spring barley (Hordeum vulgare L.). Plant, Soil and Environment. 57(12): 547-552.

Shen, B., Allen, W.B., Zheng, P., Li, C., Glassman, K., Ranch, J., Nubel, D. and Tarczynski, M.C. (2010). Expression of Zmlec1 and Zmwri1 increases seed oil production in maize. Plant Physiology. 153(3): 980-987.

Silva, R.R., Zucareli, C., Fonseca, I.C.D.B., Riede, C.R. and Gazola, D. (2019). Nitrogen management, cultivars and growing environments on wheat grain quality. Revista Brasileira de Engenharia Agrícola e Ambiental. 23(11): 826-832.
Tang, C., Yang, X., Chen, X., Ameen, A. and Xie, G. (2018). Sorghum biomass and quality and soil nitrogen balance response to nitrogen rate on semiarid marginal land. Field Crops Research. 215: 12-22.

Telleng, M., Wiryawan, K.G., Karti, P.D.M.H., Permana, I.G. and Abdullah, L. (2016). Forage production and nutrient composition of different sorghum varieties cultivated with indigofera in intercropping system. Media Peternakan. 39(3): 203-209.

Valkama, E., Salo, T., Esala, M. and Turtola, E. (2013). Grain quality and $\mathrm{N}$ uptake of spring cereals as affected by nitrogen fertilization in northern conditions: A meta-analysis. Agricultural and Food Science. 22(2): 208-222. 